\title{
Physical, Microbial, and Chemical Qualities of Dangke Produced by Different Temperatures and Papain Concentrations
}

\author{
A. N. Mukhlisah ${ }^{a}$, I. I. Arief ${ }^{b}$, \& E. Taufik ${ }^{b, *}$ \\ aStudy Program of Animal Production and Technology, Faculty of Animal Science, Graduate School, \\ Bogor Agricultural University \\ bDepartment of Animal Production and Technology, Faculty of Animal Science, Bogor Agricultural University \\ Jalan Agatis, Kampus IPB Darmaga Bogor 16680, Indonesia \\ (Received 18-10-2016; Reviewed 24-11-2016; Accepted 01-02-2017)
}

\begin{abstract}
Dangke, a dairy product of cow or buffalo, is a traditional food of Enrekang, South Sulawesi Province. Addition of papain in dangke preparation is responsible for the formation of solid texture of dangke. This study was aimed to find optimum conditions (temperature and concentration of papain enzyme) and their effects on physical, chemical, microbiological, and hedonic qualities of dangke. This study consisted of two stages: preparation of papain and dangke production with heating temperatures $\left(70,80\right.$, and $\left.90{ }^{\circ} \mathrm{C}\right)$ and papain treatments $(0.2 \%, 0.3 \%$, and $0.4 \%)$. The experiment was conducted in a completely randomized design with a $3 \times 3$ factorial arrangement with three replicates. The first factor was the processing temperature consisted of 3 levels i.e., 70,80 , and $90{ }^{\circ} \mathrm{C}$. The second factor was the papain concentration consisted of 3 levels i.e., $0.2 \%, 0.3 \%$, and $0.4 \%$. The obtained data were evaluated using analysis of variance (ANOVA), followed by Duncan's Multiple Range Test to observe the significances among treatments. Papain and amino acids were characterized using descriptive methods and organoleptic study was performed by non-parametric test (Kruskal-Wallis). The highest protein concentration was found in commercial papain (Merck, $360.63 \mathrm{mg} / 100 \mathrm{~g}$ ), while the protein content of papain used in this study was of $323.21 \mathrm{mg} / 100 \mathrm{~g}$. However, these enzymes had similar molecular weight of $19.17 \mathrm{kDa}$. The optimum condition of dangke preparation was found at heating temperature of $80{ }^{\circ} \mathrm{C}$ and $0.3 \%$ of papain concentration, resulting in the most desirable characteristics of dangke in terms of chemical, physical, and microbiological properties as well as hedonic evaluation.
\end{abstract}

Keywords: dangke, heat temperature, papain concentration, quality of dangke

\section{ABSTRAK}

Dangke merupakan produk olahan susu sapi atau kerbau yang merupakan makanan tradisional yang berasal dari Kabupaten Enrekang, Provinsi Sulawesi Selatan. Penambahan papain pada dangke akan berperan dalam mengubah dangke menjadi padat akibat terjadinya pemisahan protein dan air. Penelitian ini bertujuan untuk mempelajari pengaruh optimasi suhu dan konsentrasi papain pada kualitas dangke, terutama pada uji fisik, kimia, mikrobiologi, dan mutu hedonik. Penelitian ini terdiri atas 2 tahap, yaitu pembuatan enzim papain dan penentuan suhu pemanasan $\left(70,80\right.$, dan $\left.90{ }^{\circ} \mathrm{C}\right)$, dan konsentrasi papain $(0.2 \%, 0.3 \%$, dan $0.4 \%)$. Penelitian dilakukan dalam rancangan acak pola faktorial $3 \times 3$ dengan ulangan sebanyak 3 kali. Faktor pertama adalah suhu pemanasan $\left(70,80\right.$, and $\left.90^{\circ} \mathrm{C}\right)$ dan faktor kedua adalah konsentrasi papain $(0.2 \%, 0.3 \%$, dan $0.4 \%)$. Data kualitas kimia, fisik, dan mikrobiologi dianalisis menggunakan ANOVA dan dilanjutkan dengan uji jarak berganda Duncan. Identifikasi enzim papain dan asam amino dianalisis menggunakan metode deskriptif. Data organoleptik diuji secara nonparametrik (Kruskal-Wallis). Hasil konsentrasi protein tertinggi terdapat pada papain komersial (Merck, $360.63 \mathrm{mg} / 100 \mathrm{~g}$ ), sedangkan papain hasil penelitian ini memiliki konsentrasi protein $323.21 \mathrm{mg} / \mathbf{1 0 0 g}$. Hasil elektroforesis menunjukkan bahwa enzim papain hasil penelitian ini memiliki bobot molekul yang sama dengan enzim papain komersial, yaitu 19.17 kDa. Kualitas dangke terbaik berdasarkan kualitas kimia, fisik, mutu hedonik, dan mikrobiologis yang masih di bawah ambang batas cemaran koliform, kapang, dan khamir diperoleh pada suhu pemanasan $80{ }^{\circ} \mathrm{C}$ dan konsentrasi papain $0.3 \%$.

Kata kunci: dangke, konsentrasi papain, kualitas dangke, suhu pemanasan

*Corresponding author:

E-mail: epitaufik@apps.ipb.ac.id 


\section{INTRODUCTION}

Milk is a perishable product, primarily resulted from microbial contamination (Malaka, 2010), thus further processing is required. One of the products of processing is dangke. Dangke, a dairy product of Enrekang, South Sulawesi, is a processed milk from cow or buffalo. The presence of papain leads to the formation of solid structure of dangke due to water-protein separation. The characteristics of dangke including physical, chemical, and organoleptic properties are influenced by the levels of papain addition and heating process (Kesuma et al. (2013). In dangke, the presence of lactic acid bacteria was reported by (Syah et al., 2016) and a total of $30 \mathrm{LAB}$ isolates were successfully isolated from dangke and 5 isolates were successfully identified by $16 \mathrm{~S}$ rRNA gene sequencing.

Papain latex is commonly recognized by local people as a coagulant. However, scientific reports related to its effects on dangke characteristics are limited. Consequently, traditional technology is still used to produce dangke. Although dangke is a popular product in South Sulawesi, its shelf life and quality of dangke have still remained challenges to be investigated (Arum et al., 2014). The product processing and handling need to be optimized, including levels of papain addition and heating treatment. Therefore, this research was designed to observe the effects of various papain concentrations and heating temperatures on dangke properties (chemical, physical, and microbial characteristics).

Therefore, different heating temperatures and papain concentrations in dangke production were investigated to obtain desirable and pathogen-free dangke. The present study was aimed to evaluate the effect of different heating temperatures and papain concentrations on physical, chemical, microbiological, and organoleptical qualities of dangke.

\section{MATERIALS AND METHODS}

Dangke was prepared in Laboratory of Animal Product Technology, while the dangke quality was evaluated in Integrated Laboratory of Department of Animal Production Science and Technology, Faculty of Animal Science, Bogor Agricultural University (IPB).

\section{Isolation of Papaya Latex (Geantaresa \& Supriyanti, 2010)}

The papaya (var. California, age 2.5-3 months) latex was isolated in Cihideung Kramat, Bogor, Indonesia. The incisions were made in fruit surface (1-2 $\mathrm{mm}$ in depth) from the base to the end of the fruit every $4 \mathrm{~d}$ for $28 \mathrm{~d}$ in the morning (5.30-8.00 am). The latex was immediately collected and stored for the next steps.

\section{Purification of Papaya Latex into Papain (Nitsawang et al., 2006)}

Papaya latex was diluted by adding a solution of $40 \mathrm{mM}$ cysteine (3:1), and the $\mathrm{pH}$ of the mixture was ad- justed to 5.6. The suspension was filtered and adjusted to $\mathrm{pH}$ of 9.0. Precipitated fraction was then centrifuged $(9000 \times \mathrm{g}, 30 \mathrm{~min})$ and protein was precipitated by adding $\left(\mathrm{NH}_{4}\right)_{2} \mathrm{SO}_{4}$ until saturation of $45 \%$ to obtain a salt solution. The solution was then stirred and centrifuged (9000×g, $30 \mathrm{~min})$. The precipitate obtained was dissolved in $20 \mathrm{mM}$ cysteine and added with $\mathrm{NaCl}(10 \% \mathrm{w} / \mathrm{v})$. The mixture was centrifuged to precipitate papain. The enzyme obtained was tested using Lowry method and SDS PAGE.

\section{Determination of Optimum Heating Temperature and Papain Concentration}

The pasteurized cow's milk at 70,80 , and $90^{\circ} \mathrm{C}$ were added papain that was previously diluted with distilled water (1:9) with the concentrations of diluted papain of $0.2 \%, 0.3 \%$, and $0.4 \%$, respectively. The mixtures of milk and papain were then stirred until a syneresis (separation of curd and whey) was done. The curd was then filtered and shaped using coconut shell, then it was pressed until reaching a solid condition. All of the process was done manually by hand. The qualities of dangke products were then subsequently tested. The duration of curdling process ranged from 5 until $10 \mathrm{~min}$ depend on the papain concentration.

SDS PAGE Electrophoresis (Monti et al., 2000). Electrophoresis was performed to determine the molecular weight and confirm the purity of the papain used. The selected fraction was collected and analyzed by SDS PAGE (Bio-Rad, Hercules, CA, USA) using polyacrylamide gel $15 \%$, followed by a staining with Coomassie Brilliant Blue R250 (Sigma, St. Louis, MO, USA).

Protein Content Analysis (Lowry et al., 1951). The first reagent of $0.1 \mathrm{M} \mathrm{NaOH}$ was added $10 \mathrm{~mL}$ of $\mathrm{H}_{2} \mathrm{O}$ and $2 \% \mathrm{Na}_{2} \mathrm{CO}_{3}$. The second reagent of $1 \% \mathrm{Na}^{+} \mathrm{K}^{+}$tartrate(w/v) was added $10 \mathrm{~mL}$ of $\mathrm{H}_{2} \mathrm{O}$ and homogenized. Three milliliters of $1 \% \mathrm{Na}^{+} \mathrm{K}^{+}$tartrate was mixed with $15 \mathrm{mg} 0.5 \%$ $(\mathrm{w} / \mathrm{v}) \mathrm{CuSO}_{4} 5 \mathrm{H}_{2} \mathrm{O}$. The samples of papain were prepared and put into the test tube and added $5.5 \mathrm{~mL}$ of the second reagent, followed by the addition of $0.5 \mathrm{~mL}$ of Folin. The absorbance was read at $650 \mathrm{~nm}$ by spectrophotometer. The standard curve employed BSA (bovine serum albu$\min )$ at the concentrations of $0 ; 0.1 ; 0.2 ; 0.4 ; 0.6 ; 0.8$; and $1.0 \mathrm{mg} / \mathrm{mL}$.

\section{Chemical Quality}

The analysis of protein, water, fat, ash, and carbohydrate contents of the dangke samples were conducted according to AOAC (2005).

Amino acid analysis (Osthoff et al., 2002). The amino acid composition of the dangke was determined using high-performance liquid chromatography (HPLC). The samples were hydrolyzed with acid based on Osthoff et al. (2002). The composition of nitrogen in the total protein was determined using Kjeldahl method. 


\section{Physical Properties}

Water activity $\left(a_{w}\right)(A O A C, 2005)$. The water activity of the the dangke product was determined using $\mathrm{a}_{\mathrm{w}}$ meter (Novasina). Prior to analysis, the device was calibrated using saturated $\mathrm{NaCl}$ solution $\left(\mathrm{a}_{\mathrm{w}}\right.$ around 0.7509$)$. The samples were put into $a_{w}$ meter. The $a_{w}$ value was detectable when the device was in a completed mode.

Texture analysis (Buriti et al., 2007). The test was performed using LFRA texture analyzer, applied using Texture Expert, windows 1.20. The samples of dangke were uniformly sized, then placed on the instrument. The gel hardnesses of the dangke products were determined from the maximum force (peak value) at the first compression.

$\mathrm{pH}$ value (AOAC, 2005). The $\mathrm{pH}$ value was measured in duplo according to direct-probe method. The $\mathrm{pH}$ of the dangke product was measured using $\mathrm{pH}$ meter (Hanna Instruments, USA), first calibrated using $\mathrm{pH} 4$ and $\mathrm{pH} 7$ buffer solutions.

Yield (Sani et al., 2013). The yield was calculated using the following formula:

Yield $(\%)=$ [Final production (the weight of curd formed) / Initial production (The weight of milk used)] x $100 \%$

\section{Microbiological Analysis (ISO 7218, 1996)}

The microbiological test was immediately conducted after dangke preparation. Twenty five grams of dangke sample was dissolved in $225 \mathrm{~mL}$ of Buffer Peptone Water (BPW) and then the mixture was diluted to obtain $10^{-3}$ dilution for detection of coliform using Violet Red Bile Agar (VRBA) and molds and yeasts using Potato Dextrose Agar (PDA).

\section{Organoleptic Test (Arief et al., 2014)}

The determination of hedonic quality was tested based on the principle evaluation of the panelists involved. All of the panelists were asked to record their scorings in the form provided. The range of score used in the sensory evaluation of hedonic quality was 1 to 5. Fourty untrained panelists were used and provided explanation and guidance for hedonic quality tests for aroma, flavor, texture, and color.

\section{Statistical Analysis}

The experiment was conducted in a completely randomized design with a $3 \times 3$ factorial arrangement with three replicates. The first factor was the processing temperature consisted of 3 levels i.e., 70, 80, and $90{ }^{\circ} \mathrm{C}$. The second factor was the papain concentration consisted of 3 levels i.e., $0.2 \%, 0.3 \%$, and $0.4 \%$. The data were processed using analysis of variance (ANOVA). The significant differences between the means were determined by Duncan multiple range test $(P<0.05)$. The papain were identified using exploratory descriptive analysis, while the organoleptic test data were analyzed using non-parametric statistical test Kruskal-Wallis (Steel \& Torrie, 1993).

\section{RESULTS}

Figure 1 demonstrates that papain obtained has similar molecular weight $(<25 \mathrm{kDa})$ to commercial enzyme. SDS PAGE profiles showed that there was a band at each line (Figure 1). The results showed that the concentration of papain obtained in the papain extract used in this experiment was higher than those in commercial papain products of Merck and Paya (Table 1). The chemical characteristics of dangke i.e.protein, moisture, fat, ash, and carbohydrates are presented in Table 2 . The result showed that there was no significant interaction between heating temperature and papain concentration, but processing temperature significantly affected protein content $(\mathrm{P}<0.05)$. Whereas different papain concentrations significantly affected only protein and carbohydrate contents $(\mathrm{P}<0.05)$ (Table 2$)$. The increase in protein content of dangke was observed with the increase in the papain concentration from $0.2 \%$ to $0.3 \%$.

Table 3 presents the influences of heating temperature and papain concentration on physical properties of the dangke produced. Combination of the treatments did not significantly affect $\mathrm{a}_{\mathrm{w}^{\prime}} \mathrm{pH}$, and hardness of the

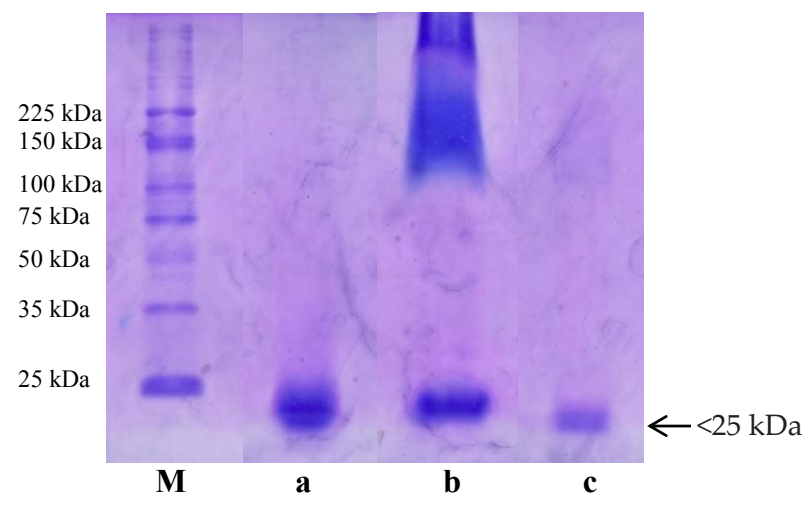

Figure 1. Electrophoresis of papain enzyme. $\mathrm{M}=$ protein marker, $\mathrm{a}=$ papain enzyme used in this study, $\mathrm{b}=$ Merck papain enzyme, $\mathrm{c}=$ the papain enzyme dilutions of $1 \%, \mathrm{BM}=$ $<25 \mathrm{kDa}$.

Table 1. Papain concentrations of several sources of papain using spectrophotometer $(650 \mathrm{~nm})$

\begin{tabular}{clc}
\hline No & Types of papain enzymes & $\begin{array}{c}\text { Papain concentra- } \\
\text { tion }(\mathrm{mg} / 100 \mathrm{~g})\end{array}$ \\
\hline 1. & Commercial Papain Paya ${ }^{\mathrm{a}}$ & 7.14 \\
2. & Commercial Papain Merck & 360.63 \\
3. & Papain produced in this study & 323.21 \\
4. & $\begin{array}{l}\text { 1\% Dilution of papain from this } \\
\text { study }\end{array}$ & 9.23 \\
\hline
\end{tabular}

Note: ${ }^{a}$ Commercially available papain; ${ }^{b}$ Papain used in dangke production. 
Table 2. Chemical characteristics of dangke produced by different temperatures and papain concentrations (\%bb)

\begin{tabular}{|c|c|c|c|c|c|}
\hline \multirow{2}{*}{ Variables } & \multirow{2}{*}{$\begin{array}{c}\text { Heating } \\
\text { temperature }\end{array}$} & \multicolumn{3}{|c|}{ Papain concentration } & \multirow{2}{*}{ Mean \pm SD } \\
\hline & & $0.2 \%$ & $0.3 \%$ & $0.4 \%$ & \\
\hline \multirow[t]{4}{*}{ Protein } & $70^{\circ} \mathrm{C}$ & $14.36 \pm 1.44$ & $16.32 \pm 0.75$ & $16.24 \pm 1.31$ & $15.64 \pm 1.16^{\mathrm{ab}}$ \\
\hline & $80^{\circ} \mathrm{C}$ & $14.80 \pm 1.41$ & $16.86 \pm 1.44$ & $17.10 \pm 1.04$ & $16.26 \pm 1.29^{a}$ \\
\hline & $90^{\circ} \mathrm{C}$ & $11.88 \pm 1.58$ & $16.05 \pm 1.17$ & $14.73 \pm 2.79$ & $14.22 \pm 1.84^{\mathrm{b}}$ \\
\hline & Mean \pm SD & $13.68 \pm 1.47^{b}$ & $16.41 \pm 1.12^{\mathrm{a}}$ & $16.03 \pm 1.71^{\mathrm{a}}$ & \\
\hline \multirow[t]{4}{*}{ Water } & $70^{\circ} \mathrm{C}$ & $60.46 \pm 3.05$ & $59.78 \pm 2.79$ & $59.69 \pm 1.80$ & $61.05 \pm 2.77$ \\
\hline & $80^{\circ} \mathrm{C}$ & $60.74 \pm 1.88$ & $58.75 \pm 0.41$ & $60.57 \pm 1.77$ & $59.66 \pm 2.07$ \\
\hline & $90^{\circ} \mathrm{C}$ & $61.96 \pm 3.37$ & $60.77 \pm 3.01$ & $58.53 \pm 4.30$ & $59.60 \pm 2.62$ \\
\hline & Mean \pm SD & $59.98 \pm 2.54$ & $60.02 \pm 1.35$ & $60.42 \pm 3.56$ & \\
\hline \multirow[t]{4}{*}{ Fat } & $70^{\circ} \mathrm{C}$ & $12.62 \pm 2.28$ & $13.76 \pm 3.78$ & $15.62 \pm 6.90$ & $14.00 \pm 4.32$ \\
\hline & $80^{\circ} \mathrm{C}$ & $13.30 \pm 0.46$ & $15.19 \pm 2.05$ & $13.55 \pm 1.67$ & $14.01 \pm 1.39$ \\
\hline & $90^{\circ} \mathrm{C}$ & $10.98 \pm 1.16$ & $12.09 \pm 2.25$ & $17.51 \pm 8.27$ & $13.53 \pm 3.89$ \\
\hline & Mean \pm SD & $12.30 \pm 1.30$ & $13.68 \pm 2.68$ & $15.56 \pm 5.61$ & \\
\hline \multirow[t]{4}{*}{ Ash } & $70^{\circ} \mathrm{C}$ & $2.15 \pm 0.25$ & $2.32 \pm 0.14$ & $2.19 \pm 0.08$ & $2.22 \pm 0.15$ \\
\hline & $80^{\circ} \mathrm{C}$ & $2.24 \pm 0.34$ & $2.31 \pm 0.21$ & $2.36 \pm 0.17$ & $2.30 \pm 0.24$ \\
\hline & $90^{\circ} \mathrm{C}$ & $2.08 \pm 0.07$ & $2.21 \pm 0.16$ & $2.08 \pm 0.25$ & $2.12 \pm 0.16$ \\
\hline & Mean \pm SD & $2.15 \pm 0.22$ & $2.28 \pm 0.17$ & $2.21 \pm 0.16$ & \\
\hline \multirow[t]{4}{*}{ Carbohydrate } & $70^{\circ} \mathrm{C}$ & $10.39 \pm 2.85$ & $7.80 \pm 6.79$ & $6.24 \pm 5.75$ & $8.14 \pm 5.13$ \\
\hline & $80^{\circ} \mathrm{C}$ & $9.86 \pm 3.19$ & $5.88 \pm 2.51$ & $6.86 \pm 3.82$ & $7.53 \pm 3.17$ \\
\hline & $90^{\circ} \mathrm{C}$ & $13.08 \pm 1.62$ & $8.86 \pm 1.51$ & $7.13 \pm 1.05$ & $9.69 \pm 1.39$ \\
\hline & Mean \pm SD & $11.11 \pm 2.55^{\mathrm{a}}$ & $7.51 \pm 3.60^{\mathrm{ab}}$ & $6.74 \pm 3.54^{\mathrm{b}}$ & \\
\hline
\end{tabular}

Note: Means in the same column and row with different superscripts differ significantly $(\mathrm{P}<0.05)$.

Table 3. Physical characteristics of dangke produced by using different heating temperatures and concentrations of papain

\begin{tabular}{|c|c|c|c|c|c|}
\hline \multirow{2}{*}{ Variables } & \multirow{2}{*}{$\begin{array}{c}\text { Heating } \\
\text { temperature }\end{array}$} & \multicolumn{3}{|c|}{ Papain concentration } & \multirow{2}{*}{ Mean \pm SD } \\
\hline & & $0.2 \%$ & $0.3 \%$ & $0.4 \%$ & \\
\hline \multirow[t]{4}{*}{ aw } & $70^{\circ} \mathrm{C}$ & $0.86 \pm 0.01$ & $0.87 \pm 0.01$ & $0.87 \pm 0.01$ & $0.87 \pm 0.01$ \\
\hline & $80^{\circ} \mathrm{C}$ & $0.87 \pm 0.00$ & $0.87 \pm 0.01$ & $0.87 \pm 0.01$ & $0.87 \pm 0.01$ \\
\hline & $90^{\circ} \mathrm{C}$ & $0.87 \pm 0.01$ & $0.87 \pm 0.01$ & $0.87 \pm 0.01$ & $0.87 \pm 0.01$ \\
\hline & Mean \pm SD & $0.87 \pm 0.00$ & $0.87 \pm 0.01$ & $0.87 \pm 0.01$ & \\
\hline \multirow[t]{4}{*}{$\mathrm{pH}$} & $70^{\circ} \mathrm{C}$ & $6.62 \pm 0.06$ & $6.62 \pm 0.12$ & $6.58 \pm 0.12$ & $6.61 \pm 0.10$ \\
\hline & $80^{\circ} \mathrm{C}$ & $6.63 \pm 0.09$ & $6.62 \pm 0.09$ & $6.61 \pm 0.08$ & $6.62 \pm 0.09$ \\
\hline & $90^{\circ} \mathrm{C}$ & $6.58 \pm 0.16$ & $6.57 \pm 0.16$ & $6.52 \pm 0.19$ & $6.56 \pm 0.17$ \\
\hline & Mean \pm SD & $6.61 \pm 0.10$ & $6.60 \pm 0.12$ & $6.57 \pm 0.13$ & \\
\hline \multirow[t]{4}{*}{ Yield (\%) } & $70^{\circ} \mathrm{C}$ & $15.54 \pm 1.01^{\mathrm{a}}$ & $15.77 \pm 1.18^{\mathrm{a}}$ & $16.96 \pm 1.62^{\mathrm{a}}$ & $16.09 \pm 1.27$ \\
\hline & $80^{\circ} \mathrm{C}$ & $16.79 \pm 2.91^{\mathrm{a}}$ & $15.66 \pm 2.31^{\mathrm{a}}$ & $15.23 \pm 1.66^{\mathrm{a}}$ & $15.89 \pm 2.29$ \\
\hline & $90^{\circ} \mathrm{C}$ & $10.29 \pm 0.55^{\mathrm{b}}$ & $15.93 \pm 1.01^{\mathrm{a}}$ & $16.10 \pm 1.79^{a}$ & $14.11 \pm 1.12$ \\
\hline & Mean \pm SD & $14.21 \pm 1.49$ & $15.79 \pm 1.50$ & $16.10 \pm 1.69$ & \\
\hline \multirow[t]{4}{*}{ Hardness (gf) } & $70^{\circ} \mathrm{C}$ & $600.90 \pm 150.80$ & $954.70 \pm 297.10$ & $829.00 \pm 63.90$ & $794.80 \pm 170.60^{\mathrm{ab}}$ \\
\hline & $80^{\circ} \mathrm{C}$ & $770.80 \pm 106.90$ & $752.00 \pm 18.50$ & $1020.60 \pm 60.60$ & $847.80 \pm 62.00^{a}$ \\
\hline & $90^{\circ} \mathrm{C}$ & $435.80 \pm 42.40$ & $719.10 \pm 32.80$ & $887.10 \pm 132.30$ & $680.70 \pm 69.10^{\mathrm{b}}$ \\
\hline & Mean \pm SD & $602.50 \pm 100.00^{\mathrm{b}}$ & $808.60 \pm 116.10^{a}$ & $912.20 \pm 85.60^{\mathrm{a}}$ & \\
\hline
\end{tabular}

Note: Means in the same column and row with different superscripts differ significantly $(\mathrm{P}<0.05)$.

dangke product, but showed a significant different in yield $(\mathrm{P}<0.05)$. Significant effects on dangke texture (Table 3) were observed as result of the treatments.

The microbiological profile of dangke is presented in Table 4 There was no significant interaction effect of heating temperatures and papain concentration on microbial profile of dangke produced $(\mathrm{P}>0.05)$. However, heating temperatures and papain concentration significantly affected total coliform in dangke produced $(\mathrm{P}<0.05)$.

Table 5 presents organoleptic evaluation (flavor, aroma, color, and texture) of dangke produced. The heating temperature and papain concentration showed significant effects on the flavor $(\mathrm{P}<0.05)$. However, heat- 
Table 4. Coliforms, molds, and yeasts contents of dangkes produced by different heating temperatures and concentrations of papain $(\log \mathrm{cfu} / \mathrm{g})$

\begin{tabular}{lccccc}
\hline \multirow{2}{*}{ Variables } & Papain & \multicolumn{3}{c}{ Heat temperature } & \multirow{2}{*}{ Mean \pm SD } \\
\cline { 2 - 5 } & concentration & $0.2 \%$ & $0.3 \%$ & $0.4 \%$ & $2.28 \pm 0.55^{\mathrm{a}}$ \\
\hline Coliform & $70^{\circ} \mathrm{C}$ & $2.36 \pm 0.53$ & $2.56 \pm 0.47$ & $1.93 \pm 0.10$ & $2.11 \pm 0.18^{\mathrm{ab}}$ \\
& $80^{\circ} \mathrm{C}$ & $2.53 \pm 0.49$ & $2.32 \pm 0.82$ & $1.49 \pm 0.61$ & $1.59 \pm 0.34^{\mathrm{b}}$ \\
& $90^{\circ} \mathrm{C}$ & $1.73 \pm 0.24$ & $1.67 \pm 0.92$ & $1.38 \pm 0.42$ & \\
Molds and yeast & $\mathrm{Mean} \pm \mathrm{SD}$ & $2.21 \pm 0.40^{\mathrm{a}}$ & $2.18 \pm 0.33^{\mathrm{a}}$ & $1.60 \pm 0.11^{\mathrm{b}}$ & $2.20 \pm 0.55$ \\
& $70^{\circ} \mathrm{C}$ & $1.84 \pm 0.46$ & $2.45 \pm 0.40$ & $2.31 \pm 1.02$ & $1.54 \pm 0.51$ \\
& $80^{\circ} \mathrm{C}$ & $1.76 \pm 0.83$ & $1.94 \pm 0.63$ & $0.91 \pm 1.21$ & $1.37 \pm 0.12$ \\
\hline
\end{tabular}

Note: Means in the same column and row with different superscripts differ significantly $(\mathrm{P}<0.05)$.

Table 5. Hedonic quality test of dangke produced by different heating temperatures and papain concentrations

\begin{tabular}{|c|c|c|c|c|c|}
\hline \multirow{2}{*}{ Variables } & \multirow{2}{*}{ Heat temperature } & \multicolumn{3}{|c|}{ Papain concentration } & \multirow{2}{*}{ Mean \pm SD } \\
\hline & & $0.2 \%$ & $0.3 \%$ & $0.4 \%$ & \\
\hline \multirow[t]{4}{*}{ Flavor } & $70^{\circ} \mathrm{C}$ & $4.03 \pm 0.41$ & $4.06 \pm 0.41$ & $4.07 \pm 0.45$ & $4.05 \pm 0.43^{\mathrm{a}}$ \\
\hline & $80^{\circ} \mathrm{C}$ & $4.10 \pm 0.48$ & $4.06 \pm 0.52$ & $3.97 \pm 0.56$ & $4.04 \pm 0.52^{\mathrm{a}}$ \\
\hline & $90^{\circ} \mathrm{C}$ & $3.13 \pm 0.34$ & $3.80 \pm 0.48$ & $3.90 \pm 0.60$ & $3.61 \pm 0.48^{\mathrm{b}}$ \\
\hline & Mean \pm SD & $3.75 \pm 0.41$ & $3.98 \pm 0.47$ & $3.98 \pm 0.54$ & \\
\hline \multirow[t]{4}{*}{ Color } & $70^{\circ} \mathrm{C}$ & $4.00 \pm 0.69$ & $3.86 \pm 0.77$ & $3.73 \pm 0.69$ & $3.63 \pm 1.01$ \\
\hline & $80^{\circ} \mathrm{C}$ & $3.96 \pm 0.72$ & $3.73 \pm 0.78$ & $3.83 \pm 0.75$ & $3.58 \pm 0.99$ \\
\hline & $90^{\circ} \mathrm{C}$ & $3.46 \pm 0.51$ & $3.83 \pm 0.79$ & $3.93 \pm 0.87$ & $3.59 \pm 0.80$ \\
\hline & Mean \pm SD & $3.81 \pm 0.64$ & $3.81 \pm 0.78$ & $3.83 \pm 0.77$ & \\
\hline \multirow{4}{*}{ Aroma } & $70^{\circ} \mathrm{C}$ & $3.73 \pm 0.90$ & $3.66 \pm 1.06$ & $3.48 \pm 1.07$ & $3.63 \pm 1.01$ \\
\hline & $80^{\circ} \mathrm{C}$ & $3.73 \pm 0.87$ & $3.58 \pm 1.07$ & $3.41 \pm 1.04$ & $3.58 \pm 0.99$ \\
\hline & $90^{\circ} \mathrm{C}$ & $3.50 \pm 0.51$ & $3.41 \pm 1.07$ & $3.86 \pm 1.07$ & $3.59 \pm 0.80$ \\
\hline & Mean \pm SD & $3.65 \pm 0.76$ & $3.55 \pm 1.07$ & $3.59 \pm 0.98$ & \\
\hline \multirow[t]{4}{*}{ Texture } & $70^{\circ} \mathrm{C}$ & $3.50 \pm 0.97$ & $3.33 \pm 0.88$ & $3.33 \pm 0.76$ & $3.39 \pm 0.87$ \\
\hline & $80^{\circ} \mathrm{C}$ & $3.36 \pm 0.96$ & $2.97 \pm 0.85$ & $3.00 \pm 0.87$ & $3.11 \pm 0.89$ \\
\hline & $90^{\circ} \mathrm{C}$ & $2.76 \pm 0.57$ & $3.47 \pm 0.89$ & $3.47 \pm 0.89$ & $3.23 \pm 0.79$ \\
\hline & Mean \pm SD & $3.21 \pm 0.84$ & $3.26 \pm 0.88$ & $3.27 \pm 0.84$ & \\
\hline
\end{tabular}

Note: Means in the same column and row with different superscripts differ significantly $(\mathrm{P}<0.05)$. Flavor: $1=$ very sour; $2=$ sour; $3=$ sourish; $4=$ tasteless; $5=$ very tasteless. Color: $1=$ yellow; $2=$ yelowish; $3=$ whitish; $4=$ white; $5=$ very white. Aroma: $1=$ very rancid; $2=$ putrid; $3=$ less putrid; $4=$ special milk; $5=$ not putrid. Texture: $1=$ very hard, not padded; $2=$ hard; $3=$ paddish; $4=$ soft, padded; $5=$ very padded.

ing temperature and papain concentration did not affect aroma, color, and texture of the dangke produced.

\section{DISCUSSION}

\section{Molecular Weight and Concentration of Papain}

SDS PAGE profiles showed that there was a single band at each sample line. The enzyme that extracted from this study and commercial papain have the same molecular weight which is $<25 \mathrm{kDa}$. As expected, this finding is in accordance with previous study (Monti et al., 2000) reporting that the molecular weight of purified fresh papaya latex was $21 \mathrm{kDa}$, detected in a single band.

The purification and dialysis methods used in this study may contribute to this result, suggesting that the high quality enzyme was successfully prepared by the methods. However, high levels of protein may result from non-enzyme proteins extracted by ammonium sulfate. The enzyme from dialysis still contained nonenzyme proteins, although it was free from non-protein contaminants (Putri et al., 2013). On precipitation with salt, ions will have an effect on the protein solubility. In low concentration, salt ions were enclose the protein molecules and protein molecules that prevent the merging or dissolving protein called salting-in. On the other hand at high concentration, the increase in electrical charge aroud the protein coat that will draw water from the collodial protein causing the hydrophobic interaction amongst the protein molecules in the atmosphere will reduce the solubility of ionic protein called saltingout (Putri et al., 2013). 


\section{Chemical Characteristics of Dangke}

Table 2 showed that protein content increased at the heating temperature of $80^{\circ} \mathrm{C}$, but decreased at $90^{\circ} \mathrm{C}$. This indicated that the excessive heating of milk could affect the dangke production. However, pasteurization of fresh milk is still needed to reduce the pathogenic and spoilage bacteria and spoilage bacteria that also affect the quality of dangke produced. Alpay \& Uygun (2015) stated that dairy products are products that are easily contaminated by bacteria. The bacteria that contaminate dairy products are pathogenic and spoilage bacteria. Handling process can be applied to pasteurization and ultra-high temperature processing (UHT). The activity of papain enzyme decreased $20 \%$ on heating treatment upto $70{ }^{\circ} \mathrm{C}$ for $30 \mathrm{~min}$ (Putri et al., 2013). Yuniwati et al. (2008) argued that heating treatment could promote protein denaturation, causing the change in its structure. Denaturation decreased solubility and enhanced its viscosity, called as coagulation.

This might be caused by the addition of papain consequently increases its activity. Pardede et al. (2013) stated that the optimum coagulation could be achieved at the proper enzyme activity, and this condition was obtained with the sufficient enzyme for the reaction and media for the activity. The addition of papain as biocatalyst influences protein content because papain has a protease activity. Protease degrades protein by hydrolyzing peptide bonds.

Lactose is a disaccharide consisting of glucose and galactose (Pardede et al., 2013). Carbohydrate content of the dangke produced was decrease to the lowest level when the heating temperatures were $80^{\circ} \mathrm{C}$ and $90^{\circ} \mathrm{C}$, which was indicated by a high water content in the dangke produced. This was in accordance with Fox et al. (2004) reported that carbohydrate content was inversely related to moisture content. The lower water content was attributed to the higher milk sugar (carbohydrate). Lactose found in milk is in the real solution phase with only $20 \%$ solubility at room temperature. Thus, levels of lactose or carbohydrate in dangke depends on the water content (Kesuma et al., 2013).

\section{Physical Characteristics of Dangke}

The lowest yield was observed at $90{ }^{\circ} \mathrm{C}$ heating temperature and $0.2 \%$ papain concentration. High heating temperature might be less effective as optimum temperature for its activity was $60-70{ }^{\circ} \mathrm{C}$. Besides, low papain concentration would lead to a low syneresis. This finding is in line with Malle et al. (2015) reporting that the decline of papain activity is found at the temperature of $70{ }^{\circ} \mathrm{C}$ and $\mathrm{pH} \mathrm{7.0.} \mathrm{According} \mathrm{Yuniwati} \mathrm{et} \mathrm{al.}$ (2008) one of the factors that influence yield of cheese are the used of protein and fat content of milk, fluctuations in protein and fat content of milk gave a major influence of dangke yield which resulted at fixed level of water content. Result shows that higher fat and protein content of milk, give the higher yield obtained. Papain is more desirable compared to other proteolytics such as bromelain and ficin since it has heating-stable properties, wider $\mathrm{pH}$ range, and highe purity. Pardede et al.
(2013) explained that in exceed enzyme concentration, the substrate availability was insufficient for optimum enzyme activity.

The obtained mean values of water activity $\left(\mathrm{a}_{\mathrm{w}}\right)$ showed a similar value (0.87). This similar value is due to similar aw testing done immediately after manufacturing dangke. Herawati (2008) revealed that water in food acts as a solvent for some components and participates as a reactant, and moderate forms of water can be found as a free water and a bound water. The $\mathrm{pH}$ value of dangke was relatively alkaline due to ripening process. Fox et al. (2004) reported that extreme $\mathrm{pH}$ levels (too low or too high) were associated with a soft and fragile texture of dangke.

The increased enzyme concentration resulted in a higher hardness, which might be caused by the formation of cross-linking or gel matrix induced by papain. Anggraini et al. (2013) reported that, principally, there are two processes that support the clotting reaction of milk protein which is hydrologic K-casein enzymatic and non-enzymatic process, trapping fat through the formation of crosslinking or gel matrix. A decrease in the $\mathrm{pH}$ of the milk causes the release of calcium ions from calcium caseinate due to the increased break down of the calcium phosphate compounds. The outbreak of calcium phosphate compound causes the stability of casein wobbly, causing coagulation. The process did not consider the time for pressing the curd and weight needed to press. The pressing was done manually by hand because there is no machine available for dangke production. Riebroy et al. (2008) clearly showed that apart from waterloss, denaturation and gelation of protein in the food system swere indeed related to the texture as it was mainly dealing with shearforce or gel strengh.

\section{Microbiological Analysis}

European Commision Regulation No. 2073 (EC, 2005) determined that maximum threshold for coliform contamination was $3 \log \mathrm{cfu} / \mathrm{g}$. Our result indicated that the contamination was under the threshold. The coliform is non-heat resistant, in accordance with Fitoni et al. (2013) that heating treatment above $60{ }^{\circ} \mathrm{C}$ for $15 \mathrm{~min}$ could provide lethal effect to coliform bacteria such as $E$. coli. Further research of Arum et al. (2014) showed that papain and non-proteolytic component of papaya latex which were extracted with ethanol also demonstrated the ability to inhibit the growth of S. aureus to $90 \%$ the TSB media. The mechanism of inhibition of $S$. aureus by dried papaya latex, papain, and the ethanol extract of papaya latex is to cause damage to their cell membranes. Besides, papain potentially had antibacterial properties due to the presence of such components as flavonoids, alkaloids, tannins, triterpenoids, seroid, and saponin (Miskiyah et al., 2011).

Total number of molds and yeasts found in the study exceeded the under threshold in dairy products. The maximum limit of molds and yeasts contamination in dairy products (solid and semi-solid) was 2.39 $\log \mathrm{cfu} / \mathrm{g}$ IS (2015). High water activity might cause the increase in total molds and yeasts. Most of yeasts could 
grow better at the sufficient water supply (Bryden, 2007).

\section{Organoleptic Quality}

The score from panelists on the heat temperature treatment was 3.61-4.05, which was perceived as tasteless. The papain treatment also promoted tasteless flavor. This might be due to the absence of ripening process on dangke, while the bitter taste might be from papain.

Texture is a palpation or touch-associated sense. The organoleptic test on dangke texture was in a moderately soft. The soft texture of the dangke resulted from a high water content. This finding is in accordance with Yerlikaya \& Karagozlu (2011) stating that texture is one of the consumer ratings for determining the food product quality and as a direct observable parameter. Sensory attributes also reflected the consumer acceptance. Texture of cheese was influenced by several components such as water, protein, and fat. The hardness is defined as the force of senses required to press the meal between the teeth, mouth, and palate, which the positive absolute peak is obtained from the first suppresion (Puspitasari et al., 2013).

\section{CONCLUSION}

The concentration of protein extracted from papaya latex was $323.21 \mathrm{mg} / 100 \mathrm{~g}$, which was almost equivalent to the commercial papain of Merck (360.63 mg/100g), and these enzymes had similar molecular weight of less than $25 \mathrm{kDa}$. The optimum condition of dangke preparation was found at heating temperature of 80 ${ }^{\circ} \mathrm{C}$ and $0.3 \%$ of papain addition, resulting in the most desirable characteristics of dangke in terms of chemical, physical, microbiological properties, as well as hedonic evaluation.

\section{ACKNOWLEDGEMENT}

This study was financially supported by Ir. H. Andi Muhammad Hasbi Munarka, MS. and the Directorate General of Higher Education, Ministry of National Education of Indonesia (DIKTI) through the 2015 Science and Technology Research Program (064/SP2H/ PL/Dit.Libtabmas/5/2015).

\section{REFERENCES}

Alpay, P. \& D. A. Uygun. 2015. Usage of immobilized papain for enzymatic hydrolysis of proteins. J. Mol. Catal. B: Enzym. 111: 56-63. https://doi.org/10.1016/j.molcatb.2014.11.001

Anggraini, R. P., A. H. D. Rahardjo, \& R. S. S. Santosa. 2013. Pengaruh level enzim bromelin dari nanas masak dalam pembuatan tahu susu terhadap rendemen dan kekenyalan tahu susu. Jurnal Ilmiah Peternakan 1: 507-513.

AOAC. 2005. Official Methods of Analysis of AOAC International. AOAC International.

Arief, I., T. Suryati, D. Afiyah, \& D. Wardhani. 2014. Physicochemical and organoleptic of beef sausages with teak leaf extract (Tectona grandis) addition as preservative and natural dye. Int. Food Res. J. 21: 2033-2042.
Arum, R. H., B. Satiawihardja, \& H. D. Kusumaningrum. 2014. Aktivitas antibakteri getah pepaya kering terhadap Staphylococcus aureus pada dangke. Jurnal Teknologi dan Industri Pangan 25: 65-71.

Bryden, W. L. 2007. Mycotoxins in the food chain: human health implications. Asia Pac. J. Clin. Nutr. 16: 95-101.

Buriti, F. C., H. R. Cardarelli, T. M. Filisetti, \& S. M. Saad. 2007. Synbiotic potential of fresh cream cheese supplemented with inulin and Lactobacillus paracasei in co-culture with Streptococcus thermophilus. Food Chem. 104: 1605-1610. https://doi.org/10.1016/j.foodchem.2007.03.001

[EC] European Commision Regulation No. 2073. 2005. No. 2073 Microbiological criteria for foodstuffs.

Fitoni, C. N., M. T. Asri, \& M. T. Hidayat. 2013. Pengaruh pemanasan filtrat rimpang kunyit (Curcuma llonga) terhadap pertumbuhan koloni bakteri Coliform secara in vitro. Jurnal Mahasiswa Teknologi Pendidikan 2: 217-221.

Fox, P. F., P. L. McSweeney, T. M. Cogan, \& T. P. Guinee. 2004. Cheese: chemistry, physics and microbiology: general aspects. Academic Press.

Geantaresa, E., \& F. T. Supriyanti. 2010. Pemanfaatan ekstrak kasar papain sebagai koagulan pada pembuatan keju cottage menggunakan bakteri Streptococcus thermophillus, Lactococcus lactis, dan Leuconostoc mesentroides. Jurnal Sains dan Teknologi Kimia 1: 38-43.

Herawati, H., 2008. Penentuan umur simpan pada produk pangan. Jurnal Litbang Pertanian 27: 124-130.

[IS] Food Safety and Standards Authority of India. (2015). Food Products Standards and Food Additives. 1-110(2)

[ISO] International Organization For Standardization. (1996). Microbiology of food and animal feeding stuffs- General rules for microbiological examinations. ISO 7218:1996(E)

Kesuma, F. M. V., S. M. Sayuthi, A. N. A. Baarri, \& A. M. Legowo. 2013. Karakteristik dangke dari susu dengan waktu inkubasi berbeda pasca perendaman dalam larutan laktoferin. Jurnal Aplikasi Teknologi Pangan 2: 155-158.

Lowry, O. H., N. J. Rosebrough, A. L. Farr, \& R. J. Randall. 1951. Protein measurement with the Folin phenol reagent. J. Biol. Chem. 193: 265-275.

Malaka, R., 2010. Pengantar Teknologi Susu. Masagena Press, Makassar.

Malle, D., I. Telussa, \& A. A. Lasamahu. 2015. Isolasi dan karakterisasi papain dari buah pepaya (Carica papaya l) jenis daun kipas. Indonesian Journal of Chemistry Research 2: 182-189.

Miskiyah, S., Usmiati, \& Mulyorini. 2011. Pengaruh enzim proteolitik dengan bakteri asam laktat probiotik terhadap karakteristik dadih susu sapi. Jurnal Ilmu Ternak dan Veteriner 16: 304-311.

Monti, R., C. A. Basilio, H. C. Trevisan, \& J. Contiero. 2000. Purification of papain from fresh latex of Carica papaya. Braz. Arch. Biol. Technol. 43: 501-507. https://doi. org/10.1590/S1516-89132000000500009

Nitsawang, S., R. Hatti-Kaul, \& P. Kanasawud. 2006. Purification of papain from carica papaya latex: aqueous two-phase extraction versus two-step salt precipitation. Enzyme Microb. Technol. 39: 1103-1107. https://doi. org/10.1016/j.enzmictec.2006.02.013

Osthoff, G., A. Hugo, \& H. Venter. 2002. Study of the changes in protein fractions and amino acids of an unfermented south african dried sausage. The Journal of Food Technology in Africa 7: 101-108. https://doi.org/10.4314/jfta.v7i3.19241

Pardede, B. E., Adhitiyawarman, \& S. Arreneuz. 2013. Pemanfaatan enzim papain dari getah buah pepaya (Carica papaya L) dalam pembuatan keju cottage menggunakan bakteri Lactobacillus bulgaricus. Jurnal Kimia Khatulistiwa 2(3).

Puspitasari, R., R. S. S. Santosa, \& M. Sulistyowati. 2013. Pengaruh lama pemanasan dan pemberian level papain 
terhadap kekenyalan dan kesukaan tahu susu. Jurnal Ilmiah Peternakan 1: 501-506.

Putri, R. A., A. Kusrijadi, \& A. Suryatna. 2013. Kajian penggunaan amonium sulfat pada pengendapan enzim protease (papain) dari buah pepaya sebagai koagulan dalam produksi keju cottage. Jurnal Sains dan Teknologi Kimia 4: 159-168.

Riebroy, S., S. Benjakul, \& W. Visessanguan. 2008. Properties and acceptability of Som-fug, a Thai fermented fish mince, inoculated with lactic acid bacteria starters. LWT - Food Science and Technology 41: 569-580. https://doi. org/10.1016/j.lwt.2007.04.014

Sani, R. N., F. C. Nisa, R. D. Andriani, \& J. M. Maligan. 2013. Analisis rendemen dan skrining fitokimia ekstrak etanol mikroalga laut Tetraselmis chuii. Jurnal Pangan dan Agroindustri 2: 121-126.
Steel, R., \& J. Torrie. 1993. Prinsip dan Prosedur Statistika. Terjemahan Oleh. B. Sumantri. PT. Gramedia, Jakarta.

Syah, S. P., C. Sumantri, I. I. Arief, \& E. Taufik. 2016. Isolation and identification of indigenous lactic acid bacteria by sequencing the 16S rRNA from dangke, a traditional cheese from Enrekang, South Sulawesi. Pakistan Journal of Nutrition : in press.

Yerlikaya, O. \& C. Karagozlu. 2011. Effects of ripening period on textural and sensory properties of capper cheeses. J. Anim. Vet. Adv. 10: 1171-1176. https://doi.org/10.3923/ javaa.2011.1171.1176

Yuniwati, M., Yusran, \& Rahmadany. 2008. Pemanfaatan Enzim Papain Sebagai Penggumpal dalam Pembuatan Keju. Jurnal Sains dan Teknologi 3: 129-130. 